\title{
Variation of surface electric field during geomagnetic disturbed period at Maitri, Antarctica
}

\author{
N Jeni Victor, C Panneerselvam* and C P Anil Kumar \\ Equatorial Geophysical Research Laboratory, Indian Institute of Geomagnetism, Krishnapuram, \\ Tirunelveli 627 011, India. \\ *Corresponding author.e-mail: panneer.iig@gmail.com
}

The paper discusses on the variations of the atmospheric vertical electric field measured at sub-auroral station Maitri $\left(70^{\circ} 75^{\prime} \mathrm{S}, 11^{\circ} 75^{\prime} \mathrm{E}\right)$, and polar station Vostok $\left(78.5^{\circ} \mathrm{S}, 107^{\circ} \mathrm{E}\right)$ during the geomagnetic disturbances on 25-26 January 2006. Diurnal variation of surface electric field measured at Maitri shows a similar variation with worldwide thunderstorm activity, whereas the departure of the field is observed during disturbed periods. This part of the field corresponds to the magnetospheric/ionospheric (an additional generator in the polar regions) voltage generators. Solar wind parameters and planetary indices represent the temporal variation of the disturbances, and digital fluxgate magnetometer variation continuously monitored to trace the auroral movement at Maitri. We have observed that the electrojet movement leaves its signature on vertical and horizontal components of the DFM in addition; the study infers the position of auroral current wedge with respect to Maitri. To exhibit the auroral oval, OVATION model is obtained with the aid of DMSP satellite and UV measurements. It is noted that the Maitri is almost within the auroral oval during the periods of disturbances. To examine the simultaneous changes in the vertical electric field associated with this magnetic disturbance, the dawn-dusk potential is studied for every UT hours; the potential was obtained from Weimer model and SuperDARN radar. The comparison reveals the plausible situation for the superposition of dawn-dusk potential on surface electric field over Maitri. This observation also shows that the superposition may not be consistent with the phase of the electrojet. Comparison of surface electric field at Maitri and Vostok shows that the parallel variation exhibits with each other, but during the period of geomagnetic disturbances, the influence is not much discerned at Vostok.

\section{Introduction}

The atmospheric global electric circuit is a current system in which currents flow upward from thunderstorm current generators, through the ionosphere, and down to the Earth's surface in the fair weather regions. Continuous measurements of atmospheric electrical parameters, namely, the vertical electric field, the conductivity, and the air-Earth current, that characterize the global electric circuit (GEC) are considered useful in any study with the aim of understanding fully the electrical environment of the Earth. Further, since the global electric circuit links the lower troposphere, the ionosphere and the magnetosphere, the measurement of atmospheric electrical parameters will be useful in any integrated approach that involves all these regions (Bering 1995; Rycroft et al. 2000). Long term measurements from various sites would be considered useful for addressing some of the problems associated with the global change. Despite a long history and good number of observations carried

Keywords. Atmospheric electric field; magnetic storm; magnetosphere; ionosphere; global electrical circuit. 
out for more than four decades (Kasemir 1955; Byrne et al. 1993; Burns et al. 1995; Bering et al. 1998; Deshpande and Kamra 2001; Virkkula et al. 2005; Panneerselvam et al. 2007a, b, 2010; Anil Kumar et al. 2008, 2009, 2013), knowledge of the relations between atmospheric electricity, solar cycle, climate and air pollution is insufficient for extensive applications. Hence, the non-linear effect may be important in the real atmospheric electrical processes because the thunderstorms are non-steady, and the electric charges may play an important role in the thunderstorm electrification (Chiu 1978; Mathpal et al. 1980; Kuettner et al. 1981; Mathpal and Varshneya 1982). Many studies suggested that the solar activity influences due to ionospheric electric field disturbances may significantly control the global electric circuit state (Sao 1967; Apsen et al. 1988; Michnowski 1998; Bering et al. 1998; Rycroft et al. 2000; Frank-Kamenetsky et al. 2001; Nikiforova et al. 2003).

Measurements over polar regions are of great importance in understanding GEC as these regions are practically free from anthropogenic pollution. Since maximum parts of the continent are covered by ice, the ionization produced by the radioactivity element at ground surface is almost absent. The electrical conductivity of the ice surface is in several orders of magnitude higher than that of air (Cobb 1977). The atmospheric electrical studies at Antarctica are useful for investigating the largescale electrical process which is unique at high latitudes (Byrne et al. 1993; Panneerselvam et al. 2007a, b, 2010; Anil Kumar et al. 2009; Kleimenova et al. 2012). The global electric circuit involves lower atmosphere generators (mostly controlled by the thunderstorm) and upper atmosphere generators (ionosphere/magnetosphere), the most important of which are at the high latitude (polar caps) (Richmond 1986; Roble and Tzur 1986). The influence of this external generator on surface electric field is dependent on magnetic coordinates of the measuring site. Atmospheric electrical parameters have been measured at Maitri and reported by many authors, local summer (Panneerselvam et al. 2007a, b), influence on coronal mass ejection (Anil Kumar et al. 2008), electrodynamic coupling function (Anil Kumar et al. 2009), etc. Panneerselvam et al. (2007a) reported that the surface electric field measurement at Maitri is similar like 'Carnegie curve', the so-called thunderstorm generated electric field pattern. He further stated that the classic diurnal variation is not regularly seen on individual days but it only emerged when many days are averaged (Anil Kumar et al. 2008, 2009).

An additional problem while trying to study the global electric circuit at the high latitude-polar-cap region is that horizontal ionospheric electric fields map downward to the Earth's surface (Richmond
1986; Roble and Tzur 1986; Burns et al. 2005; Anil Kumar et al. 2009). This dawn-to-dusk horizontal potential difference due to the interaction of the solar wind with the Earth's magnetosphere $(\mathrm{V} \times \mathrm{B})$ causes the two-cell convection pattern in the polar region. In this part, the principal component analysis was carried out by Panneerselvam et al. (2007a), using surface electric field data at Maitri, and they stated that the first eigen value gives information about the thunderstorm contribution to the global electric circuit. The second and third components will give the information about the E-region ionosphere dynamo and the solar wind-magnetosphere dynamo, respectively. The currents and electric fields produced by the ionospheric wind dynamo are relatively weak in comparison with those of solar windmagnetosphere dynamo at high latitude during solar active time, since cross-polar cap potential has a significant influence in high-latitude region and extended up to $40^{\circ}$ magnetic co-latitudes (Hairston and Heelis 1990; Tinsley 2008). The extended horizontal electric field is (dawn-dusk potential) gradually downward to the lower atmosphere. The clockwise cell would map to increase the upward vertical electric field and current at the ground. The anti-clockwise convection would map down to decrease to the measured atmospheric electric field and current (Park 1976). The nature of the convective cell depends on the relative position of the station with respect to magnetic dawn to dusk. Solar wind induced changes can be involved by more direct effects of the deep penetration of the interplanetary electric field into middle- and lowlatitude ionosphere. The strongest manifestations of the solar wind interactions with the magnetosphere and ionosphere processes are especially evident at the auroral and polar latitudes. Many studies of surface electric field associated with these effects have been carried out at high and polar Arctic and Antarctic areas (Reddell et al. 2004; Kleimenova et al. 2008 and references therein) but the magnetospheric/ionospheric contribution to atmospheric electricity at sub-auroral stations is discussed by few researchers (Anil Kumar et al. 2009; Panneerselvam et al. 2010; Minamoto and Kadokara 2011; Odzimek et al. 2011; Frank-Kamenetsky et al. 2012; Luk' yanova et al. 2011). Frank-Kamenetsky et al. (2012) noted that the correlation between variation in the surface electric field at high latitude and the calculated horizontal electric potential (Weimer_05 model) are insignificant, and the correlation is relatively linked with the occurrence of auroral electrojet. However, no consistent results were drawn from earlier studies and a similar approach was not used at the equatorward auroral boundary stations.

In this paper, we have attempted to discuss the temporal variation of surface electric field measured at Maitri $\left(70^{\circ} 45^{\prime} 52^{\prime \prime} \mathrm{S}, 11^{\circ} 44^{\prime} 03^{\prime \prime} \mathrm{E}, 117 \mathrm{~m} \mathrm{amsl}\right)$ and 
Vostok $\left(78^{\circ} 27^{\prime} 52^{\prime \prime} \mathrm{S}, 106^{\circ} 50^{\prime} 14^{\prime \prime} \mathrm{E}, 3488 \mathrm{~m}\right.$ amsl) and its departure during the geomagnetic disturbed periods.

\section{Experimental technique}

Widely used ground-based sensors for the measurement of air-Earth current are the Wilson plate (Israel 1973), the horizontal long-wire antenna (Kasemir 1955; Ruhnke 1969; Panneerselvam et al. 2010). The atmospheric electric field has been measured at Maitri with the field mill made out of nonmagnetic stainless steel to reduce the contact potentials. The sensor plates and rotor in the field mill are of $8.5 \mathrm{~cm}$ diameter. The shaft of the ac motor $(220 \mathrm{~V}, 50 \mathrm{~Hz}, 1500 \mathrm{rpm})$ is grounded with a carbon bush. The signal from the field mill is amplified with Op-Amp 1596, which is mounted inside the field mill. The maintenance and calibration methodology of the instruments were briefly explained in Panneerselvam et al. (2004) and Manu et al. (2013). This instrument was installed on flat barren land near the station and the site description along with meteorological parameters impact were briefly described in Deshpande and Kamra (2001).

\section{Data selection and analysis}

In this work, we have used the vertical atmospheric electric field which is measured at Maitri on 25-26 January 2006, under the so-called 'fair-weather' conditions, i.e., free from snowfall, surface wind speed $<10 \mathrm{~m} \mathrm{~s}^{-1}$, cloud coverage less than 4 octa, etc. Solar wind and IMF parameters were obtained from the advanced composition explorer (ACE) (http://www.srl.caltech.edu/ACE/) satellite and AE (auroral electrojet index), 3-hourly $\mathrm{K}_{\mathrm{p}}$ index data were archived from the World Data Centre (WDC) (http://wdc.kugi.kyoto-u.ac.jp/aeasy/ index.html). The occurrences of aurora are identified using the digital flux gate magnetometer (DFM) at Maitri. The hourly averaging procedure is performed for all the parameters since it is most suited for identification of the signatures of the global electric circuit (Panneerselvam et al. 2007a, b, 2010; Anil Kumar et al. 2009, 2013). Normalized diurnal variation of typical fair-weather day atmospheric electric field $\left(\mathrm{E}_{\mathrm{NZQ}}\right)$ measured at Maitri is depicted in figure 1; it is a mean curve of 69 'fairweather' days during summer from 2001 to 2004 at Maitri, Antarctic. Normalization is performed based on the following equation,

$$
\operatorname{Ezn}(\mathrm{hr})=\mathrm{Ez}(\mathrm{hr}) / \operatorname{mean}(\mathrm{Ez}(\text { day })) \text {. }
$$

Normalization of experimental data reduces the dispersion, revealing a regular change of measured

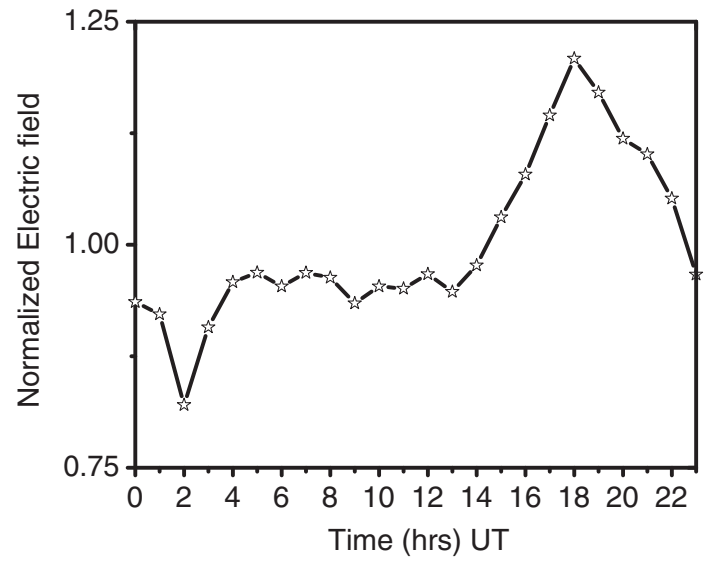

Figure 1. Diurnal variation of normalized atmospheric electric field $\left(\mathrm{E}_{\mathrm{NZQ}}\right)$ averaged over 69 fair weather days at Maitri, Antarctica (Panneerselvam et al. 2007a).

parameters as a function of universal time. The diurnal variation of atmospheric electric field during the fair weather days at Maitri, Antarctic follows the famous Carnegie's curve with a minimum at about nearly 03:00 UT and a maximum about nearly 19:00 UT (Panneerselvam et al. 2007a). Therefore, this curve is treated as reference curve for further analysis in this work.

Geomagnetic storm is generally defined as an enhancement of main phase due to the westward ring current followed by the recovery phase. The magnetic storm main phase is usually accompanied by high latitude geomagnetic substorm that manifest large magnetosphere-ionosphere disturbances seen in energetic particle precipitations and ionosphere potential configuration changes (Kleimenova et al. 2008). In high latitude, the status of geomagnetic disturbances classified as, based on the $\mathrm{K}_{\mathrm{p}}$ index, 0 $<\mathrm{K}_{\mathrm{p}}<3$ is considered as a magnetic quiet period i.e., low/no geomagnetic disturbance, $4<\mathrm{K}_{\mathrm{p}}<7$ is moderately disturbed, and more than this, indicates the strong geomagnetic storm (Rangarajan and Barreto 1999). Maitri is away from auroral oval influence during magnetically quiet time and is encompassed by the auroral oval, under magnetically disturbed conditions (Panneerselvam et al. 2010). Part of the day-to-day variations on ground-level electric field may be ascribed to the solar wind/ magnetospheric and ionospheric contribution during magnetically disturbed periods. Figure 2 shows an hourly variation of normalized electric filed $\left(\mathrm{E}_{\mathrm{NZ}}\right)$ on 25-26 January 2006 along with the reference curve $\left(\mathrm{E}_{\mathrm{NZQ}}\right)$. Time series of surface electric field shows a typical fair-weather field pattern on both the days. In addition, the field departure is observed between 19:00 UT on 25 January and 03:00 UT on 26 January 2006, and the similar kind of enhancement is observed during evening hours on the same day. The hourly variation of geomagnetic 


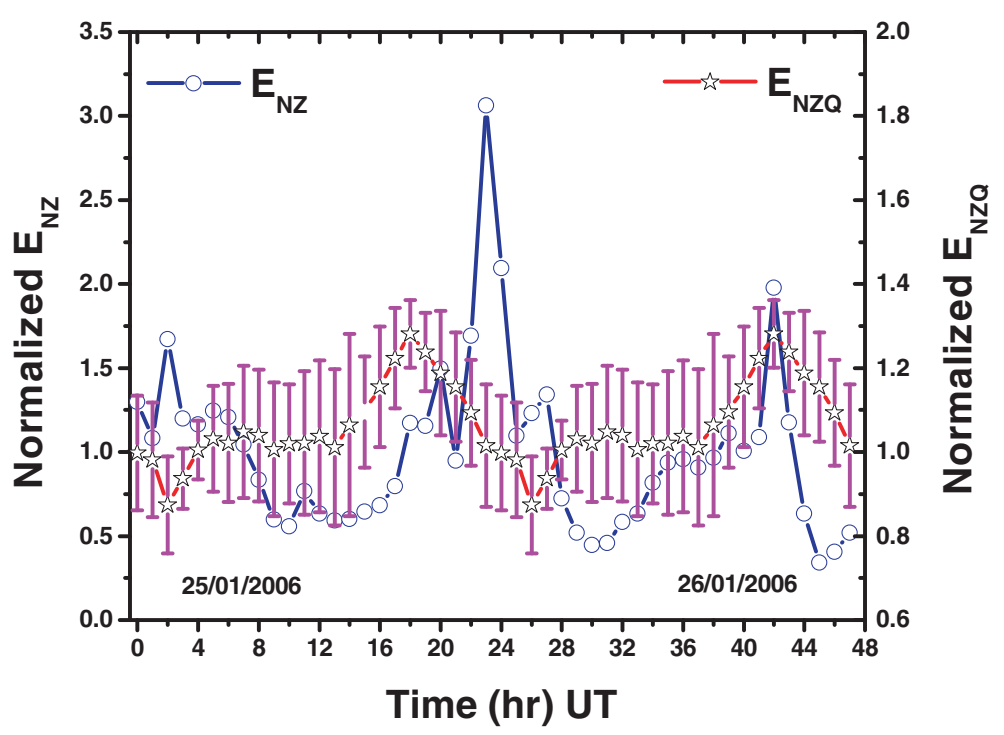

Figure 2. Comparison of observed atmospheric electric filed ( $\left.\mathrm{E}_{\mathrm{NZ}}\right)$ on 25-26 January 2006 and $\mathrm{E}_{\mathrm{NZQ}}$ at Maitri, Antarctica. Right side axis represents the normalized value for reference curve. Left side axis represents the normalized value of electric field at Maitri.

indices, solar wind parameters and ground magnetometer on 25-26 January 2006 is shown in figure 3. These parameters collectively express the geomagnetic disturbance that occurred on $25-$ 26 January 2006, in which, panel (a-c) describes the strength and the movement of auroral electrojet at Maitri. SYM-H shows moderate magnetic disturbances at 16:00 UT on 25 January and its amplitude is intensified of $-66 \mathrm{nT}$ at about 03:00 UT on the next day. A positive hump is observed in the $\Delta \mathrm{Z}$ component at 18:00-20:00 UT due to the approaching of auroral current wedge towards Maitri, and it further enhanced at 04:00 UT where the current wedge was dominated over the location. The recovery phase indicates the motion of the current wedge that moved away from Maitri. Simultaneous variation is noticed on $\Delta \mathrm{H}$ component except that the initial disturbance registered on $\Delta \mathrm{Z}$ as shown in figure 3(c). A thick solid line signifies the UT hour at which the maximum deviation occurred by focussing on magnetic field component, at 04:00 $\mathrm{UT}$, along with the variation of planetary index. To trace the motion of auroral current with respect to latitudes, the magnetic field components are widely used. The hourly variation of interplanetary parameters on 25-26 January 2006 is shown in panel $(\mathrm{e}-\mathrm{h})$. The dotted lines focus on the variation of aforesaid parameters during the period of disturbances, where the onset of southward phase $\left(B_{z}<0\right)$ is noticed in IMF $B_{Z}$ at 16:00 $\mathrm{UT}$, and it further progressed up to post-midnight hours as depicted in panel 'e'. In the meantime, IMF east-west $\left(\mathrm{B}_{\mathrm{y}}\right)$ component remains eastward $\left(B_{y}>0\right)$. The solar wind speed $\left(V_{s w}\right)$ shows gradual increasing trend during the period of interval, whereas the number density clearly peaks at postmid-night hours as seen in panel $(\mathrm{g}-\mathrm{h})$. Resultant of this disturbance is represented in $\mathrm{K}_{\mathrm{p}}$ index as it varies between 3 and 4 during the same interval as shown in panel ' $\mathrm{i}$ '.

The similar kind of situation is observed during evening hours on 26 January 2006, but neither solar wind parameters nor SYM-H represents the signature of geomagnetic disturbances. It is noticeable that IMF $\mathrm{B}_{\mathrm{y}}$ (negative) describes the motion of solar plasma in the sunward direction during the period of observation.

The analysis of $\mathrm{AE}$ and $\mathrm{K}_{\mathrm{p}}$ index clearly represents the disturbance that occurred around 16:0018:00 UT, and the associated signature recorded on the Earth's magnetic field components, which is marked by solid line in panel $(\mathrm{a}-\mathrm{d})$ at 18:00 UT on 26 January 2006. In general, during the magnetic disturbances the ionosphere becomes very unstable and the ionospheric conductivity strongly enhances, especially at the auroral latitudes. As a result, the total resistance of the ionosphere part of the global electric circuit may decrease (Michnowski 1998). On account of the change in resistance of the ionosphere, surface electric field increased at about 17:00 UT over Maitri as shown in figure 2. The maximum departure of atmospheric electric field $\left(\mathrm{E}_{\mathrm{NZ}}\right)$ is observed at 18:00 UT followed by recovery phase at 19:00-21:00 UT on 26 January 2006.

Figure 7 compares the hourly variation of surface electric field at Maitri and Vostok for the entire period of observation. The axis on the left represents the field variation at Vostok and right side for Maitri. Diurnal variation of electric field pattern 
(a)

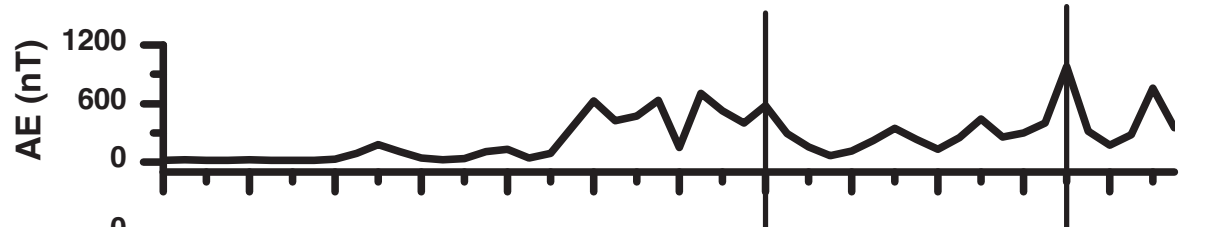

(b)



(c)

(d)

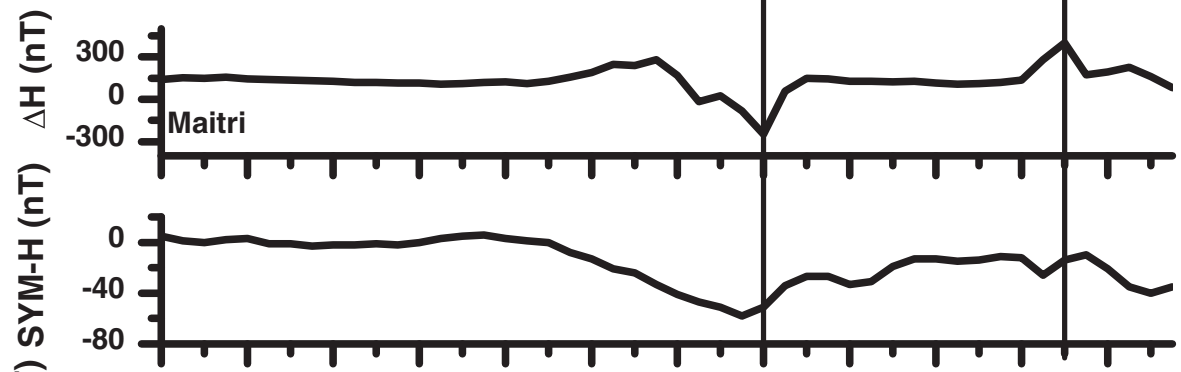

(e)

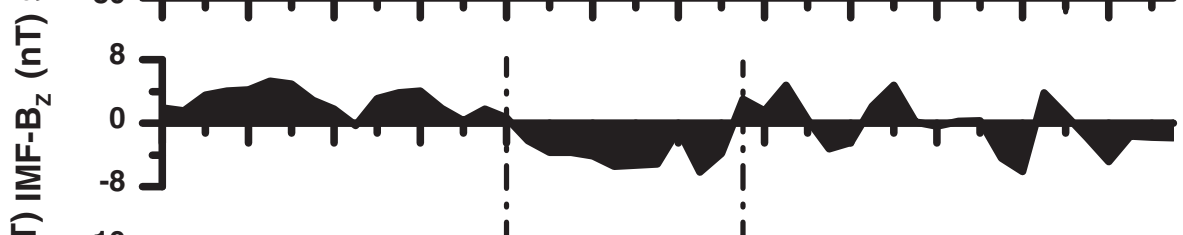

(f)

点

(g)

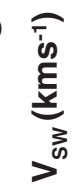

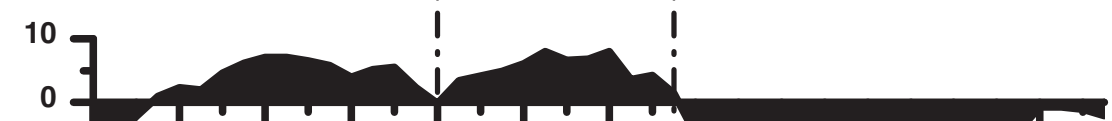

(h)

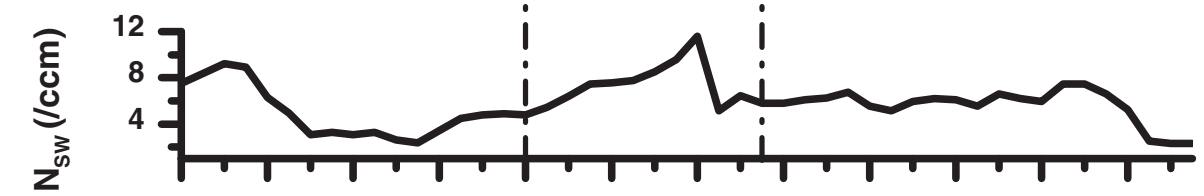

(i)



Figure 3. Hourly variation of $K_{p}$ index, solar wind, interplanetary parameters and ground magnetometer on 25-26 January 2006. Two dotted lines from panel (b-e) concentrate the variation from 16:00 UT on 25 January 2006 to 03:00 UT on 26 January 2006. The sum of $K_{\mathrm{p}}$ index is mentioned at the corner. (b) Hourly variation of IMF-BZ shows the north-south

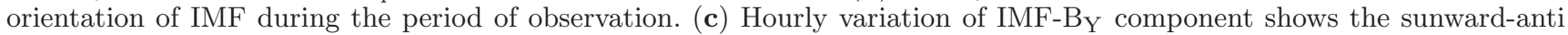
sunward orientation of IMF. (d) Hourly variation of solar wind speed ( $\mathrm{V}_{\mathrm{SW}}$ ) for two days. (e) Hourly variation of solar wind number density $\left(\mathrm{N}_{\mathrm{SW}}\right)$ on the event days. (f) Hourly variation of auroral electroject index. (g) Hourly variation of $\Delta \mathrm{Z}$ component of geomagnetic field at Maitri. (h) Hourly variation of $\Delta \mathrm{H}$ component of geomagnetic field at Maitri. (i) Hourly variation of SYM-H storm index. The first straight line indicates the UT hour of maximum disturbance and corresponding variation of aforesaid parameters on pre-morning hours on 26 January 2006. The second straight line indicates the time at which the dusk-ward particle precipitation occurred on 26 January 2006.

at Vostok is as similar as fair-weather pattern. On 25 January, field curve had a slight deviation during UT noon hours. On 26 January, the curve exactly matches with worldwide thunderstorm activity. Similarly, the field variation at Vostok has dissimilarity with the field at Maitri on 25 January, but it 
is absent on the next day as clearly seen in figure 7 . Due to the insufficient magnetic field data over south polar cap region, the electrojet influences on surface electric field could not be investigated over Vostok Observatory.

\section{Discussion}

\subsection{Event on 25 January 2006}

Surface electric field observation at Maitri clearly represents the departure of the atmospheric field during magnetically disturbed periods. Atmospheric electrical parameters measured at Maitri has been studied by many researchers who have reported that the site is suitable for the global thunderstorm measurement (Rajaram et al. 2002; Panneerselvam et al. 2003; Anil Kumar et al. 2013; Devendraa Singh et al. 2013). Figure 1 depicts one of the fine measurements during summer for the period 2001-2004. On the Antarctic plateau, electric field measurements respond to input from the solar wind (Tinsley et al. 1998; Anil Kumar et al. 2009; Panneerselvam et al. 2010; FrankKamenetsky et al. 2012). The coupling between solar wind-magnetosphere-ionosphere is more efficient only when the IMF retains the same direction for more than $3 \mathrm{hr}$ (Reiff and Luhmann 1986). On 25 January 2006, the southward phase $\left(B_{\mathrm{z}}<\right.$ $0)$ persists more than $10 \mathrm{hr}$ from 16:00 UT to the next day morning hours. This negative excursion in the IMF causes disturbances in the magnetometer at Maitri, and it is registered as sharp negative deviation on the vertical component. The negative trend generally depicts the latitudinal changes of auroral oval, moving poleward. This observation has good agreement with the results drawn from an optical auroral study at Maitri by Girija Rajaram et al. (2002). It is further reported that the horizontal component provides the information about the direction of electrojet; similarly $\Delta \mathrm{H}$ depicts the sharp negative variation due to the westward auroral electrojet (WAE) at 02:00-03:00 UT as seen in figure $3(\mathrm{~b}-\mathrm{c})$. It is evident that an intensive westward current is observed polarwards, over Maitri observatory during the same interval.

Figure 4 depicts the relative position of Maitri and Vostok with respect to auroral oval, which is archived from the OVATION model (http://sdwww.jhuapl.edu/Aurora/). As shown in figure 4(a), the travelling surges, moving towards dusk sector around 22:00 UT with respect to Maitri. The consecutive images clearly show the westward movement of an auroral current. Due to the unavailability of successive UT hour's images, the entire electrojet movement may not be depicted. However, the magnetic field components and OVATION model clearly describe the movement of auroral electrojet with respect to location over Maitri during the period of disturbances.

The interaction of the solar wind $\left(\mathrm{V}_{\mathrm{SW}}\right)$ and Earth's magnetic field $\left(\mathrm{B}_{\mathrm{T}}\right)$ provides an additional horizontal potential difference (i.e., $\mathrm{V}_{\mathrm{SW}} \times \mathrm{B}_{\mathrm{T}}$ ) at high latitudes. This additional potential difference superimposed on the global ionospheric vertical potential generated by meteorological electrical processes (Burns et al. 2012). The dawndusk potential has to be estimated in spatial and temporal scale in order to find its contribution on the surface measurements. According to the existing polar cap models (Reiff and Luhmann 1986; Weimer 1996; Boyle et al. 1997; Ye Gao et al. 2013), dawn-dusk potential represents the basic coupling function (VB $\sin ^{\mathrm{n}} \theta$ ), however, each model has its own significance. Weimer-05 model is followed in this work to obtain the potential difference for ionosphere part of the global electric circuit.

Weimer models are empirical, spherical, harmonic coefficient models, derived from a minimum-error fit of satellite ionospheric electric field measurements and coincident solar wind measurements (Weimer 1996). The following parameters are given as an input to obtain dawn-dusk potential, time (UT), geographic latitude, solar wind velocity $\left(\mathrm{V}_{\mathrm{SW}}\right)$, solar wind number density $\left(\mathrm{N}_{\mathrm{SW}}\right)$ and IMF parameters. Figure 5 depicts the stereographic projection of southern hemisphere focused on dawndusk, where the potential difference and location of Maitri are marked as PHI (kV) and 'star' symbol on the map, respectively. The high potential difference of around $\pm 50.4 \mathrm{kV}$ is observed at 22:30 UT as represented in figure 5(a), whereas the magnetic quiet time potential varied from 15 to $20 \mathrm{kV}$. This enhanced large scale horizontal potential difference map down through magnetic field lines and coupled with the vertical electric field at Earth's surface (Park 1976). The corresponding superposed electric field is acquired at about 23:00 UT in the atmospheric electric field at Maitri, where the amplitude is two-fold higher than normal fair-weather electric field at particular UT hour. This result agrees with the study performed by Tinsley et al. (1998), where the South Pole data is discussed with polar cap potential. He further stated that the direct influence of the cross polar cap potential difference can be discerned in geoelectric field measurements at South Pole.

Apart from the recent developments of existing ionospheric potential models, we have an opportunity to validate the aforesaid inferences using radar measurement. SuperDARN (SuperDual Aurora Radar Network), is an international network of highfrequency radars monitoring plasma flow in the polar ionosphere. The network database (http://www. 
SOUTH CAP

End time 25 Jan 2006-22:30

DMSP Satellite : F16

No UVI Data for this period

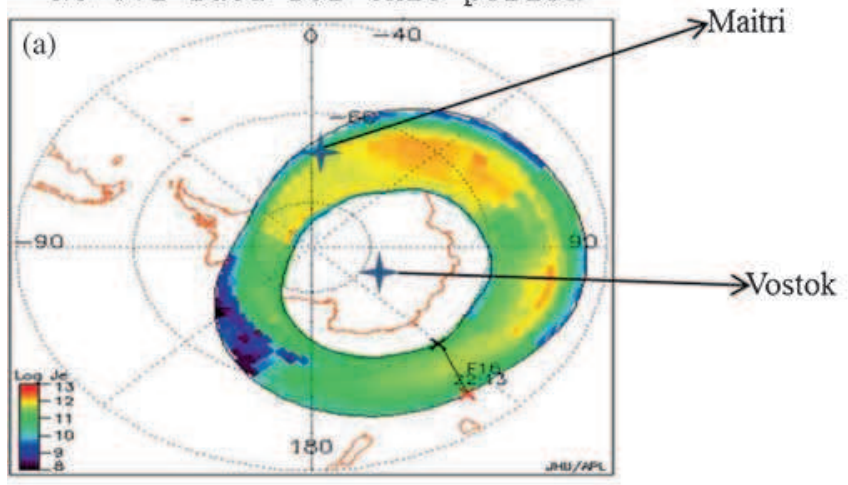

SOUTH CAP

End time 26 Jan 2006-17:45

DMSP Satellite : F16

No UVI Data for this period

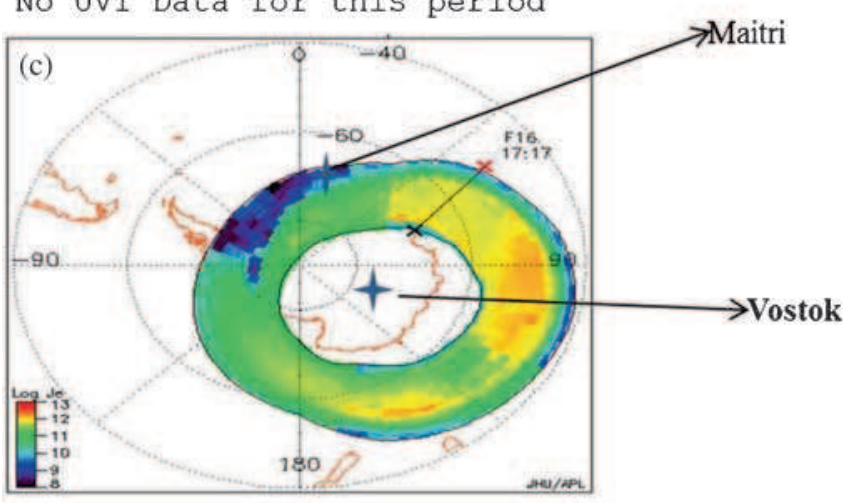

SOUTH CAP

End time 26 Jan 2006-00:00

DMSP Satellite : F16

No UVI Data for this period

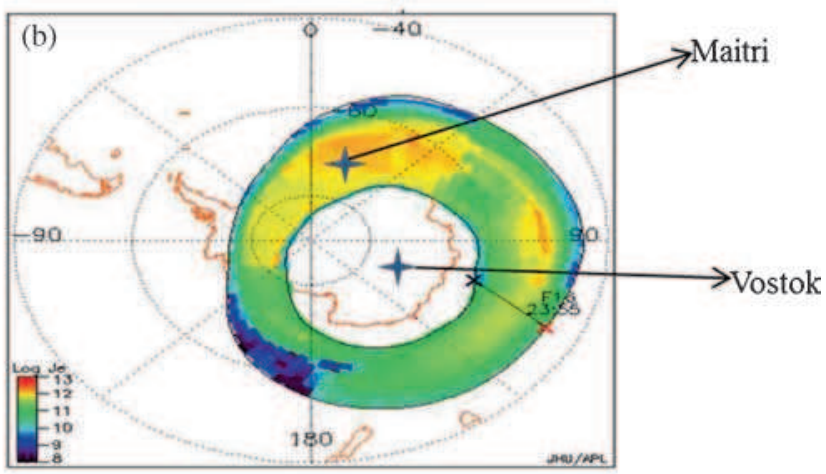

SOUTH CAP

End time 26 Jan 2006-20:30

DMSP Satellite : F16

No UVI Data for this period



Figure 4. The relative position of Maitri and Vostok to the auroral oval on 25-26 January 2006. (a) Auroral oval position over south polar cap at 22:30 UT on 25 January 2006; (b) at 00:00 UT on 26 January 2006; (c) at 17:45 UT on 26 January 2006; and (d) auroral oval position over south polar cap at 20:30 UT on 26 January 2006.

jhuapl.edu/superdarn) contains digitized convection maps with spatial resolution of $1^{\circ}$ GLat/1 hr MLT and with time resolution of $2 \mathrm{~min}$. This convection potential can be used successfully for rep resenting the dawn-dusk potential influence on the atmospheric electricity parameters (Odzimek and Lester 2009; Odzimek et al. 2011). Convection maps for geomagnetic disturbed periods have been projected in figure 6 . The outer red ring in the convection map indicates the equatorward boundary of the auroral oval and the so-called Heppner-Maynard boundary (HMB) (Suzanne Mary Imber et al. 2012). Figure 6(b) confirms the enhancement of dawndusk potential during this period of disturbances as it varies of $40 \mathrm{kV}$ at 22:00 UT, whereas figure 6(a) depicts the potential of $22 \mathrm{kV}$ during magnetic quiet time. HMB clearly indicates that Maitri is located within the auroral oval during the period of interest. Therefore, it is evident that horizontal potential model and observation mutually varied at the time of geomagnetic disturbances. This supports that the enhancement of the electric field measured at Maitri has been significantly influenced by the development of dawn-dusk potential.

\subsection{Event on 26 January 2006}

The magnetic disturbance recovered at 06:00 UT, and later the magnetometer $(\Delta \mathrm{H}$ and $\Delta \mathrm{Z})$ shows the magnetic perturbation at Maitri during late evening hours on 26 January 2006. In the absence of this, magnetic signature on the solar wind parameters and SYM-H describes that the perturbation may be localized at high latitude, possibly due to substorm phenomenon.

Figure $3(\mathrm{f}-\mathrm{g})$ shows the sunward $\left(\mathrm{B}_{\mathrm{Y}}<0\right)$ flow of plasma with high speed, this dusk-to-dawn motion of solar plasma from magneto tail along the field lines triggers the substorm activity. It is originated 
Southern Hemisphere

$01 / 25 / 2006$ Time $=22: 30: 00$

$\mathrm{V}_{\mathrm{X}}: 424.73 \mathrm{~B}_{\mathrm{y}}: 6.64 \mathrm{~B}_{\mathrm{z}}:-5.26 \mathrm{~N}: 8.50 \mathrm{Tilt}:-17.21$

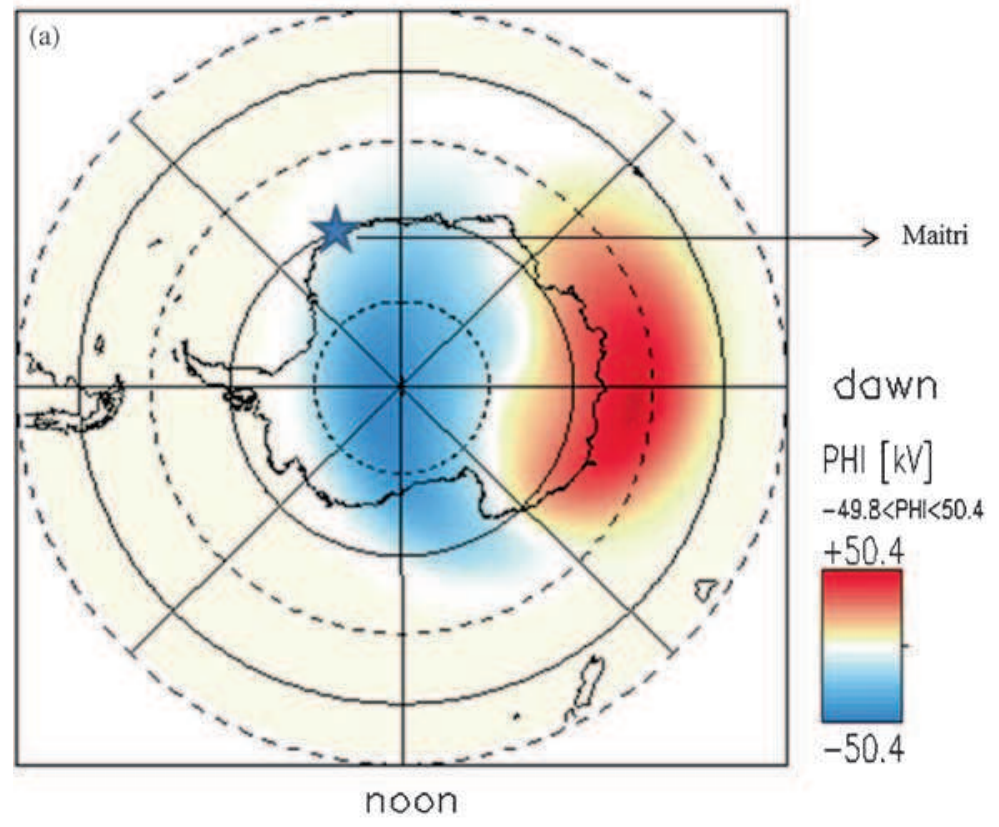

Southern Hemisphere

01/26/2006 Time $=18: 00: 00$

$\mathrm{V}_{\mathrm{X}}: 588.38 \mathrm{~B}_{\mathrm{y}}:-5.72 \mathrm{~B}_{\mathrm{z}}: 1.03 \mathrm{~N}: 7.48$ Tilt: -8.74

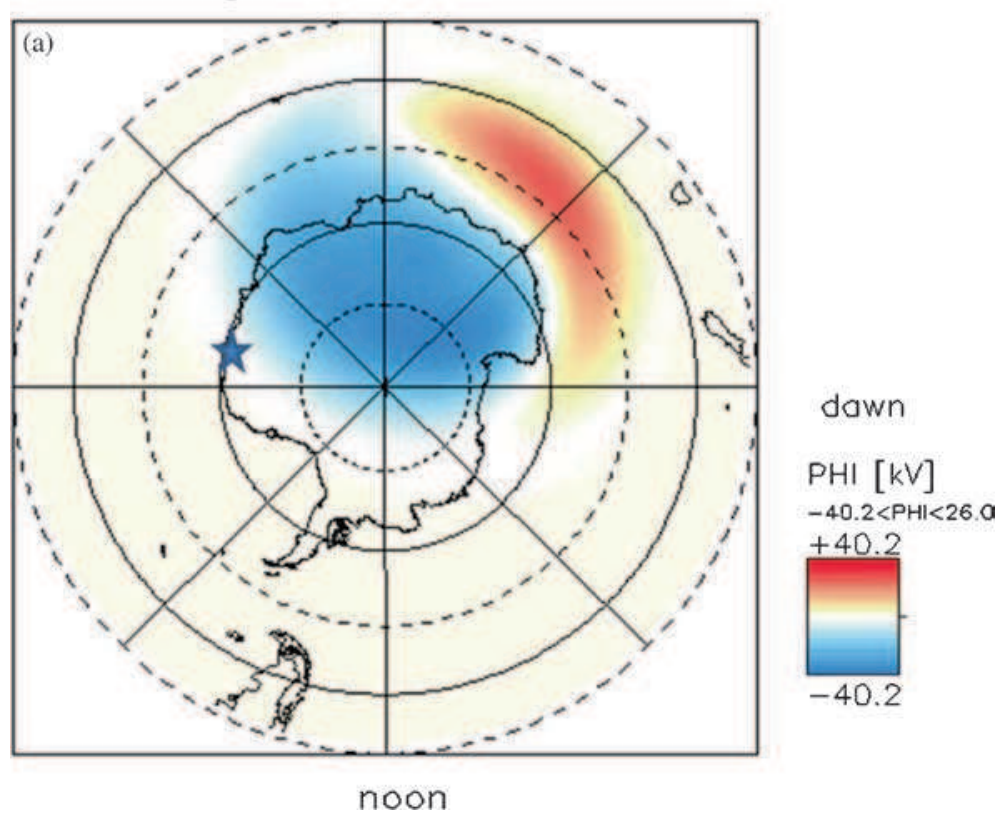

Figure 5. Electric potential pattern of southern hemisphere from the Weimer_05 model. Date, time, IMF \& solar wind parameters and tilt angle $(\theta)$ are given at the top of the panel. The maximum and minimum potential is denoted in the right side of the each panel. (a) Ionospheric electrostatic potential pattern at 22:30 UT on 25 January 2006. (b) Ionospheric potential pattern at 18:00 UT on 26 January 2006. (http://ccmc.gsfc.nasa.gov/models/modelinfo.php?model=Weimer).

by plasma instabilities in the magnetosphere tail and provides high latitude ionosphere current enhancement and energetic particle precipitation. The variations of atmospheric electric field with respect to the substorm phenomenon were studied by many authors (Bandilet et al. 1986; FrankKamenetsky et al. 2001; Kleimenova et al. 2010, 2012). These studies reported that the development of night-time magnetospheric substorm manifested itself in the variations of atmospheric electric field 

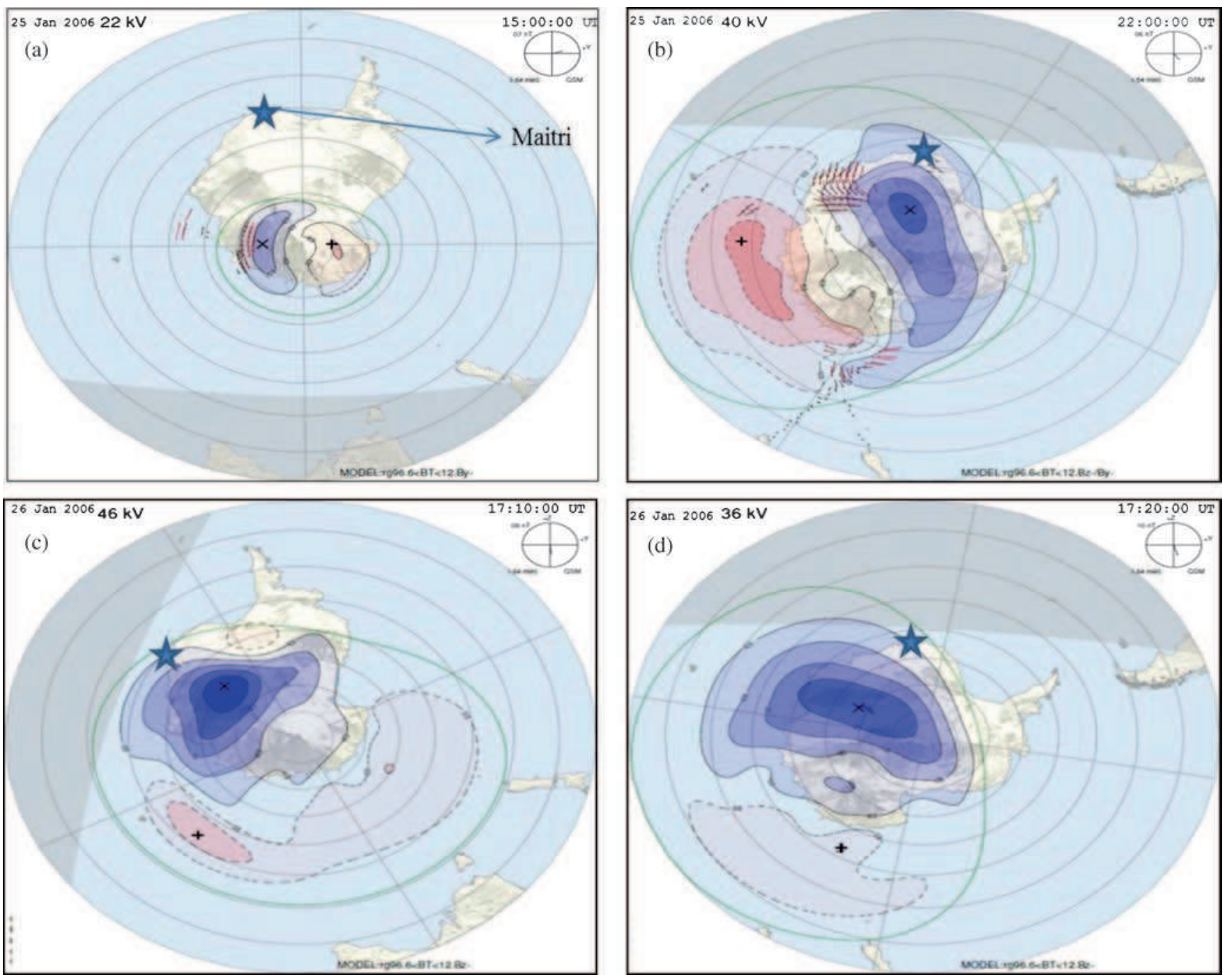

Figure 6. Maps of ionospheric convection from SuperDARN measurements on 25-26 January 2006. IMF direction and its associated potential values are given in each map. The negative and positive potential cells denoted as blue and red colour in the convection map. The 'star' symbol indicates the position of Maitri station. (a) Quite time $\left(K_{p}=2\right)$ behaviour of convection map at 15:00 UT on 25 January 2006. (b) Convection map at 22:00 UT on 25 January 2006. (c) Map at 17:10 UT on 26 January 2006. (d) Convection map at 17:20 UT on 26 January 2006.

registered at auroral latitudes. Enhancement of AE $(\sim 700 \mathrm{nT})$ and $\mathrm{K}_{\mathrm{p}}(5)$ index varying more than the quiet time range supported the substorm activity during 17:00 to 19:00 UT as seen in figure 3 (a and i). This disturbance propagates relatively to lower latitudes and leaves its signature on $\Delta \mathrm{H}$ component as a positive peak at 19:00 UT owing to eastward flow of auroral electrojet (Rajaram et al. 2002). In addition, OVATION image confirms that Maitri is under the influence of auroral oval around 17:45 UT as depicted in figure 4(c). As expected, the fair-weather electric field at Maitri shows significant response for this substorm activity, and its amplitude enhanced over $75 \%$ more than average at about 18:00 UT. The diurnal variation of of normalized electric field is almost parallel with reference curve, because the substorm and global thunderstorm activities intensified at same UT hour on 26 January 2006 as shown in figure 2. Concurrently, the ionospheric horizontal potential varied $66.2 \mathrm{kV}$ at 18:00 UT as in Weimer model, and SuperDARN map also indicated the potential enhancement of $46 \mathrm{kV}$ at 17:10 UT and $36 \mathrm{kV}$ at $10 \mathrm{~min}$ interval as depicted in figure $6(\mathrm{c}-\mathrm{d})$. This developed large scale horizontal potential map down to Earth's surface and added up with vertical electric field. This detailed observation again confirms the aforesaid inferences derived from last session.

Though the dawn-dusk potential difference between geospace disturbance and substorm is high, the superposed field effect on the surface electric field is less during substorm activity due to less affinity of the foci of convection cell to overhead 
ionosphere at Maitri. These findings agree with earlier reports (Park 1976; Hays and Roble 1979; Morozov and Troshichev 2008), which described that the atmospheric electric filed at the ground level is proportional to the potential difference between the overhead ionosphere and the earth's surface at the observation point. Recent observations (Morozov and Troshichev 2008; Rycroft et al. 2008; Kruglov and Frank-Kamenetsky 2010) also confirm the significance for superposing convection potential towards the ground electrical measurements. Later on Frank-Kamenetsky et al. (2012) analyzed the variation of electric field during the geomagnetic perturbation at sub-auroral station in northern hemisphere, and he observed that the correlation between atmospheric electric field and ionospheric potential is better when the station is under the influence of westward electrojet. Due to the limited observations carried out in this study, the significant inferences cannot be drawn in this regard.

Simultaneous measurements of ground electric field at Vostok and Maitri almost follow the Carnegie curve. Figure 4 depicts the oval image, Vostok is positioned as a 'star', during the period of disturbances where Vostok is located inside the auroral boundary. A comparative study between geo-electric field at Vostok and IMF reported that the IMF $\mathrm{B}_{\mathrm{Y}}$ has linear relation with surface electric field (Frank-Kamenetsky et al. 1999). But Luk'yanova et al. (2011) showed that when IMF $\mathrm{B}_{\mathrm{Y}}<0$, Vostok station is located below the equipotential line and the overhead ionospheric potential value changes insignificantly. Hourly variation of surface electric field at Vostok on 25-26 January 2006 has good agreement with the above findings as the electric field variation is not the manifestation of

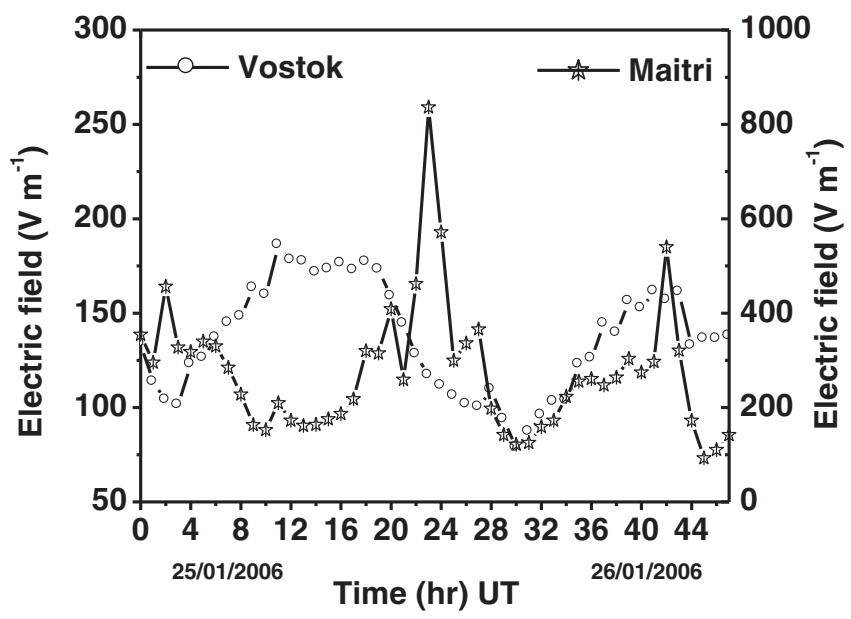

Figure 7. Comparison of surface electric field measured at Maitri and Vostok on 25-26 January 2006. Left side axis represents the electric field at Vostok and right side axis denotes the field at Maitri. geomagnetic perturbation. Moreover, on 26 January 2006, IMF $\mathrm{B}_{\mathrm{y}}$ maintained negative phase throughout the day but the surface electric field simply reflects the thunderstorm generated electric field alone. Eventually this observation shows that Vostok is under the equipotential line for the entire period of observations (figure 7).

\section{Conclusions}

We analyzed the surface electric field $\left(\mathrm{E}_{\mathrm{NZ}}\right)$ measurement at Maitri during moderate geomagnetic disturbances. Diurnal variation of the surface electric field is very good in accordance with thunderstorm generate electric field. To find out the temporal variation of the geomagnetic disturbances, the solar wind parameters and Earth's magnetic field components have been extensively studied. Vertical and horizontal magnetic field components clearly indicate the motion of the auroral electrojet over Maitri, in which the horizontal magnetic field describes the direction of electrojet. It is evident that high speed solar wind has to accompany negative $\mathrm{B}_{\mathrm{z}}$, for large scale magnetic disturbances to manifest at Maitri, and the observation consistent with the auroral oval image obtained from OVATION model. Simultaneous response is obtained from the ground electric field variation around the same interval as it is significantly enhanced due to the contribution from the magnetospheric/ionospheric generators. This enhancement is due to the superposition of large scale horizontal ionospheric potential with vertical electric field; it is obtained through Weimer model and SuperDARN data. Aforesaid inferences reveal additional information that the horizontal and vertical potentials are not always possession of one to one correlation but with some delay in time. The time shift might be attributed to the foci of the convection cells with respect to overhead of Maitri. It is further observed that the variation of surface electric field associated with the magnetic perturbation with respect to the phase of the auroral electrojet is poor. Since many existing dawn-dusk models principally focussed on polar cap where the magnetic field lines are almost vertical, extending of these models to lower latitude created perhaps quantitative imbalance and temporal variation. At Vostok Observatory, significant variations are not observed during geomagnetic disturbed periods.

From this observation, it is evident that the measurement of atmospheric electrical parameters at Maitri can be influenced by magnetospheric generators only during geomagnetic disturbed periods. Finding space weather events impact on surface electric field at different latitude depends on many 
factors along with fair-weather conditions. With the continuous measurements of atmospheric electrical parameters and geomagnetic field variations, there is scope for addressing the contemporary problems related to the modulation of GEC by the influence of magnetosphere-ionosphere coupling processes on the near-surface electrical parameters at the polar caps.

\section{Acknowledgements}

We, the authors, gratefully acknowledge referees for their valuable suggestions, which helped in making improvements on the original version. We gratefully acknowledge CDAWeb and the Kyoto Data Center for providing the ACE and geomagnetic activity indices used in this study. We acknowledge JHU/APL for getting auroral oval image under the OVATION project. We also thank the PIs of the SuperDARN radars, Daniel Weimer's models and CEDAR. The Ministry of Earth Science, Government of India, for conducting a variety of experiments at the Indian Antarctic station, Maitri, is gratefully acknowledged.

\section{References}

Anil Kumar C P, Panneerselvam C, Nair K U, Jeeva K, Selvaraj C, Gurubaran S and Rajaram R 2008 Influence of coronal mass ejections on global electric circuit; Indian J. Radio Space Phys. 37 39-45.

Anil Kumar C P, Panneerselvam C, Nair K U, Johnson Jeyakumar H, Selvaraj C, Gurubaran S and Venugopal C 2009 Apposite of atmospheric electric parameters with the energy coupling function $(\varepsilon)$ during geomagnetic storms at high latitude; Atmos. Res. 91 201-205.

Anil Kumar C P, Gopalsingh R, Selvaraj C, Nair K U, Jayakumar H J, Vishnu R, Muralidas S and Balan N 2013 Atmospheric electric parameters and micrometeorological processes during the solar eclipse on 15 January 2010; J. Geophys. Res. Atmos. 118 5098-5104, doi: 10.1002/jgrd.50437.

Apsen A G, Kanonidi K D, Chernyshova S P, Chetaev D N and Sheftel V M 1988 Magnitosfernyeeffekty v atmosfernomelektrichestve (Magnetospheric effects in atmospheric electricity); Moscow: Nauka.

Bandilet O I, Kanonidi K D, Chernysheva S P and Sheftel V M 1986 Effects of magnetospheric substorms in the atmospheric electric field; Geomagnetism and Aeronomy 26159.

Bering E A 1995 The global circuit: Global thermometer, weather by product or climate modulator; Rev. Geophys. 33 845-851.

Bering E A, Few A A and Benbrook J R 1998 The global electric circuit; Phys. Today 51(10) 2-30.

Boyle C B, Reiff P H and Hairston M R 1997 Empirical polar cap potentials; J. Geophys. Res. 102(A1) 111-125, doi: 10.1029/96JA01742.

Burns G B, Hesse M H, Parcell S K, Malachowski S and Cole K D 1995 The geoelectric field at Davis station, Antarctica; J. Atmos. Terr. Phys. 57(14) 1783-1797.
Burns G B, Frank-Kamenetsky A V, Troshichev O A, Bering E A and Reddell B D 2005 Interannual consistency of bi-monthly differences in diurnal variations of the groundlevel, vertical electric field; J. Geophys. Res. 110 D10106, doi: 10.1029/2004JD005469.

Burns G B, Tinsley A, Frank-Kamenetsky A V, Troshichev O A, French W J R and Klekociuk R 2012 Monthly diurnal global atmospheric circuit estimates derived from Vostok electric field measurements adjusted for local meteorological and solar wind influences; J. Atmos. Sci. $692061-2082$.

Byrne G J, Benbrook J R, Bering E A, Few A, Morris G, Trabucco W J and Paschal E W 1993 Groundbased instrumentation for measurements of atmospheric conduction current and electric field at the south pole; J. Geophys. Res. 98(D2) 2611-2618, doi: 10.1029/92JD02303.

Chiu C S 1978 Numerical study of cloud electrification in an axisymmetric, time-dependent cloud model; J. Geophys. Res. 83 5025-5049.

Cobb W E 1977 Atmospheric electric measurements at the south pole; In: Electrical Processes in Atmospheres (eds) Dolezalek H and Reiter R, Steinkopff, Darmstadt, Fed. Repub. Ger., pp. 161-167.

Deshpande C G and Kamra A K 2001 Diurnal variations of atmospheric electric field and conductivity at Maitri, Antarctica; J. Geophys. Res. 106 14,207-14,218.

Devendraa Siingh, Singh R P, Gopalakrishnan V, Selvaraj C and Panneerselvam C 2013 Fair-weather atmospheric electricity study at Maitri (Antarctica); Earth Planets Space 65 1541-1553.

Frank-Kamenetsky A V, Burns G B, Troshichev O A, Papitashvili V O, Bering E A and French W J R 1999 The geoelectric field at Vostok, Antarctica: Its relation to the interplanetary magnetic field and the cross polar cap potential difference; J. Atmos. Sol.-Terr. Phys. 61 13471356.

Frank-Kamenetsky A V, Troshichev O A, Burns G B and Papitashvili V O 2001 Variations of the atmospheric electric field in the near pole region related to the interplanetary magnetic field; J. Geophys. Res. 106 179190.

Frank-Kamenetsky A V, Kotikov A, Kruglov L A, Burns G B, Kleimenova N G, Kozyreva O V, Kubitski M and Odzimek A 2012 Variations in the near-surface atmospheric electric field at high latitudes and ionospheric potential during geomagnetic perturbations; Geomagnetism and Aeronomy 52(5) 629-638.

Girija Rajaram, Arun T and Ajay Dhar 2002 Diagnostics of magnetosphere-ionosphere coupling over Indian Antarctic station Maitri, from magnetometer and riometer observations during the optical auroral event of 4-5 March 1999; Adv. Space. Res. 30(10) 21952201.

Hairston M R and Heelis R A 1990 Model of the high latitude ionospheric convection pattern during southward interplanetary magnetic field, using DE2 data; J. Geophys. Res. 95 2333-2343.

Hays P B and Roble R G 1979 A quasi static model of global atmospheric electricity. 1. The lower atmosphere; J. Geophys. Res. 84 3291-3305, doi: 10.1029/JA084iA07p03291.

Israel H 1973 Atmospheric electricity, Publ. Nat. Sci. Foundation by the Israel Program for Sci. Transl.

Kasemir H W 1955 Measurement of the air-earth current density; In: Proc. Conf. Atmos. Electricity; Geophys. Res. Pap., 42, 91-95, Air Force Cambridge Res. Cent, Bedford, Mass.

Kleimenova N G, Kozyreva O V, Michnowski S and Kubicki M 2008 Effect of magnetic storms in variations in 
the atmospheric electric field at midlatitudes; Geomagn. Aeron. 48(5) 650-659 (Geomagn. Aeron. (Engl. Transl.), $200848622-630)$.

Kleimenova N G, Kozyreva O V, Kubicki M and Michnowski S 2010 Morning polar substorms and variations in the atmospheric electric field; Geomagn. Aeron. 50(1) 48-57, doi: 10.1134/S0016793210010068.

Kleimenova N G, Kozyreva O V, Kubicki M, Odzimek A and Malysheva L M 2012 Effect of substorms in the Earth's nightside sector on variations in the surface atmospheric electric field at polar and equatorial latitudes; Geomagn. Aeron. 52(4) 467-473.

Kruglov A A and Frank-Kamenetsky A V 2010 Studying the relation between the electric potential of the high latitude ionosphere and the vertical component of the near-earth electric field; TrInstPriklGeofiz 88 54-59.

Kuettner J P, Levin Z and Sartor J D 1981 Thunderstorm electrification - Inductive or non-inductive? J. Atmos. Sci. 38 2470-2484.

Luk'yanova Yu R, Kruglov A A, Frank-Kamenetsky A V, Kotikov A L, Barns G B and French V D R 2011 Relationship between the ionospheric potential and the groundlevel electric field in the southern Polar Cap; Geomagn. Aeron. 51(3) 387-396. (Geomagn. Aeron. (Engl. Transl.) 2011, 51 383-393).

Manu S, Panneerselvam C, Nair K U and Gurubaran S 2013 Design and fabrication of an electrometer for the measurement of atmospheric potential; Environ. Sci. 8(11) 442-452.

Mathpal K C, Varshneya N C and Dass N 1980 Precipitation-powered mechanisms of cloud electrification; Rev. Geophys. Space Sci. 18 361-377.

Mathpal K C and Varshneya N C 1982 Riming electrification mechanism for charge generation within a thundercloud of finite dimensions; Ann. Geophys. 38(1) 67-75.

Michnowski S 1998 Solar wind influences on atmospheric electricity variables in polar regions; J. Geophys. Res. 103D 13,939-13,948.

Minamoto Y and Kadokura A 2011 Extracting fair-weather data from atmospheric electric-field observations at Syowa Station, Antarctica; Polar Sci. 5(3) 313-318, doi: 10.1016/j.polar.2011.07.001.

Morozov V N and Troshichev O A 2008 Simulation of variations in the polar atmospheric electric field related to the magnetospheric field-aligned currents; Geomagn. Aeron. 48(6) 759-769 (Geomagn. Aeron. (Engl. Transl.) $48727-736)$.

Nikiforova N N, Kleimenova N G, Kozyreva O V, Kubicki $\mathrm{M}$ and Michnowski S 2003 Influence of auroral-latitude precipitation of energetic electrons on variations in the atmospheric electric field at polar latitudes (Spitsbergen Archipelago); Geomagn. Aeron. 43(1) 32-39 (Geomagn. Aeron. (Engl. Transl.) 43 29-35).

Odzimek A and Lester M 2009 Modeling the Earth's global atmospheric electric circuit-development, challenges and directions, In: Publs. Inst. Geophys. Pol. Acad. Sci. (eds) Baranski P and Kubicki M, D-73 (214).

Odzimek A, Kubicki M, Lester M and Grocott A 2011 Relation between SuperDARN ionospheric potential and ground electric field at polar station hornsund, Proc. 14th Int. Conf. Atmospheric Electricity, Rio de Janeiro, 2011.

Panneerselvam C, Jeeva K, Ajay Dhar, Rajaram R, Gurubaran S and Rajaram G 2004 Observations of atmospheric Maxwell current at Indian Antarctic Station, Maitri - Indian Expedition to Antarctica; Scientific Report; Tech. Publ. 17 99-105.
Panneerselvam C, Nair K U, Jeeva K, Selvaraj C, Gurubaran $\mathrm{S}$ and Rajaram R 2003 A comparative study of atmospheric Maxwell current and electric field from a low latitude station, Tirunelveli; Earth Planets Space 55 697703.

Panneerselvam C, Selvaraj C, Jeeva K, Nair K U, Anilkumar C P and Gurubaran S 2007a Fair weather atmospheric electricity at Antarctica during local summer as observed from Indian station, Maitri; J. Earth Syst. Sci. 116(3) 179-186.

Panneerselvam C, Nair K U, Selvaraj C, Jeeva K, Anil Kumar C P and Gurubaran S 2007b Diurnal variation of atmospheric Maxwell current over the low-latitude continental station, Tirunelveli, India $\left(87^{\circ} \mathrm{N}, 778^{\circ} \mathrm{E}\right)$; Earth Planet. Space 59 429-435.

Panneerselvam C, Anil Kumar C P, Ajay Dhar, Nair K U, Ajay Dhay, Selvaraj C, Gurubaran S and Pathan B M 2010 Instrumentation for the surface measurements of atmospheric electrical parameters at Maitri, Antarctica: First results; Earth Planet. Space 62 545-549.

Park C G 1976 Downward mapping of high-latitude ionospheric electric fields to the ground; J. Geophys. Res. 81(1) 168-174.

Rangarajan G K and Barreto L M 1999 Use of $K_{p}$ index of geomagnetic activity in the forecast of solar activity; Earth Planet. Space 51 363-372.

Reddell B D, Benbrook J R, Bering E A, Cleary E N and Few A A 2004 Seasonal variations of atmospheric electricity measured at Amundsen-Scott, South Pole Station; J. Geophys. Res. 109 A09308, doi: 10.1029/2004JA010536.

Reiff P H and Luhmann J G 1986 Solar wind control of the polar cap potential, in solar wind-magnetospheric coupling (eds) Kamide Y and Slavin J A, 453 Terra Sci., Tokyo.

Richmond A D 1986 Upper-atmospheric electric field sources; In: Study in Geophysics - The Earth's electrical environment; Natl. Acad. Press, Washington DC, pp. 195-205.

Roble R G and Tzur I 1986 The global atmosphere electrical circuit, in the earth's electrical environment (eds) Krider E P and Roble R G, Natl. Acad. Press, Washington DC, pp. 206- 231.

Ruhnke L H 1969 Area averaging of atmospheric electric currents; J. Geomagn. Geoelectr. 21 453-462.

Rycroft M J, Israelsson S and Price C 2000 The global atmospheric electric circuit, solar activity and climate change; J. Atmos. Sol.-Terr. Phys. 62 1563-1576.

Rycroft M J, Harrison R G, Nicoll K A and Mareev E A 2008 An overview of Earth's global electric circuit and atmospheric conductivity; Space Sci. Rev. 137 83-105, doi: 10.1007/978-0-387-87664-1-6.

Sao K 1967 Correlation between solar activity and the atmospheric potential gradient at the Earth's surface in the polar regions; J. Atmos. Sol.-Terr. Phys. 29(2) 213-215, doi: 10.1016/0021-9169(67)90135-3.

Suzanne Mary Imber, Milan S E and Lester M 2012 The Heppner-Maynard boundary measured by SuperDARN as a proxy for the latitude of the auroral oval; J. Geophys. Res., doi: 10.1029/2012ja018222.

Tinsley B A 2008 The global atmospheric electric circuit and its effects on cloud microphysics; Rep. Prog. Phys. 71 066801-066832, doi: 10.1088/0034/71/6/066801.

Tinsley B A, Weiping L, Rohrbaugh R P and Kirkland M W 1998 South Pole electric field responses to overhead ionospheric convection; J. Geophys. Res 103(D20) 61376146.

Ye Gao, Kivelson M G and Walker R J 2013 Two models of cross polar cap potential saturation compared: Siscoe-Hill 
model versus Kivelson-Ridley model; J. Geophys. Res. 118 794-803, doi: 10.1002/jgra.50124.

Virkkula A, Vana M, Hirsikko A, Aalto P A, Kulmala M and Hillamo R 2005 Air ion mobility and aerosol particle size distributions at the Finnish Antarctic research station
Aboa; In: Abstracts of the European Aerosol Conference (ed.) W Maenhaut, Elsevier, New York, 698p.

Weimer D R 1996 A flexible IMF dependent model of high-latitude electric potentials having space weather applications; Geophys. Res. Lett. 23 2549-2552.

MS received 26 March 2014; revised 4 August 2015; accepted 13 August 2015 